\title{
Cephalic Index of Adult Igbo's in Imo State, Nigeria
}

\author{
Ifunanya DMD* and Ukoha UU \\ Faculty of Basic Medical Sciences, Nnamdi Azikiwe \\ University, Okofia, Nnewi, Anambra State, Nigeria \\ *Corresponding author: Dike Martha Dora Ifunanya, \\ Faculty of Basic Medical Sciences, Nnamdi Azikiwe \\ University, Okofia, Nnewi, Anambra State, Nigeria
}

Received: June 07, 2021; Accepted: J uly 06, 2021;

Published: J uly 13, 2021

\begin{abstract}
Cephalic index is of great importance to anatomists, anthropologists and even to forensic scientists, in the determination of head shapes and for medicolegal cases. Cranial and post cranial measurements have typically been used to describe individuals and to compare groups. This study aims at obtaining the Cranial indices of adults Igbos in Imo state, which will help build the forensic database and in identification of age, gender, racial differences in recent and ancient humans, and in the diagnoses of certain developmental disorders of the skull, such as Craniosynostosis, Hydrocephalus, and Postural deformation. Also to correlate the results of males with that of females. One thousand, One hundred and fifty eight (1158) subjects comprising of five hundred and seventy nine (579) males and females respectively, ages 18-52 years. The measurements were done manually with the use of transparent graded ruler, measuring tapes, gliding and sliding calipers or flexible tapes. The following parameters were measured; cranial length, cranial breadth, since Cephalic Index=Cranial breadth/cranial length $\times 100$. The mean cranial length and breadth were $172 \pm 92.89$ and $160.46 \pm 27.65$ respectively. The result for males Cranial Length $(C L)$, Cranial Breadth (CB), were respectively 173.93 \pm 18.75 , 161.05 \pm 17.21 . The result for females Cranial Length $(C L)$, Cranial Breadth (CB), were respectively; $171.76 \pm 30.06,159.88 \pm 35.11$. These results were used to calculate the various Cephalic Index; mean Cephalic Index $(\mathrm{Cl})$ was 97.26 \pm 21.55 . The males Cephalic Index (Cl) was100.23 \pm 26.23 , and female Cephalic Index $(\mathrm{Cl})$ was $94.29 \pm 14.94$, Analysis of the results was done using independent t-test and Pearson bivariate correlation. These tests were carried out using Statistical Package for Social Sciences (SPSS version 25). Microsoft office excel was also used during data processing. Analysis showed that there was a significant difference in the mean values of females and males. The result from this study shows that Adults in Imo state are Brachycephalic. This study is a great contribution to the forensic, anthropology, anatomical and medical database.
\end{abstract}

Keywords: Cephalic index; Brachycephalic; Craniosynostosis; Hydrocephalus

\section{Introduction}

Cranial and postcranial measurements have typically been used to describe individuals and to compare groups. Before 1960, comparisons were usually based on single measurements evaluated independently or on indices that combined two dimensions as an indicator of shape. The recent availability of computers has facilitated the use of multivariate statistics and encouraged the development of increasingly sophisticated research designs [1]. Population variation in skeletal morphology is the result of genetic and environmental differences among groups. Since heritability studies have demonstrated that genes greatly influence cranial shape, it is generally assumed that groups with similar craniofacial morphology are more closely related than groups that display greater differences in cranial form. Variations of the human face are so extensive and obvious that one can distinguish even identical twins with relative ease. The reason for and substance of these variations and differences are more difficult to define, unless they are carefully studied and measured. It is well established that anthropometric parameters have indicated significant differences existing between the sexes, races and cranial variation at worldwide, regional, ethnic, or intragroup levels [2]. This craniometrical data can be used to address questions of culturalhistorical relationships, identification of ancestry, which is important in both forensic and bioarchealogical context [3]. Swedish professor of anatomy Anders Retzius (1796-1860) first used the cephalic index in physical anthropology to classify ancient human remains found in Europe, he classified brains into three main categorie [3]; Dolichocephalic, Mesocephalic, and Brachycephalic. This study was carried out to document and provide a baseline data of craniofacial measurements and Indices, which could be of importance in clinical practice, forensic, and anthropological data [4].

\section{Materials and Methods}

A total number of 1158 subjects, which comprised of 559 males and 559 females with ages ranging from 18-52 years. Participants were indigenes of Imo state whose parents and grandparents were from Imo state. Participants were seen in schools, local government areas, bars, hotels, churches; hospitals etc. participants had no facial or cranial deformities or any form of plastic or reconstructive surgery. The parameters were measured with the help of transparent graded rulers, gliding/sliding calipers or flexible tapes. All measurements were taken while the subjects were seated in a relaxed condition and 


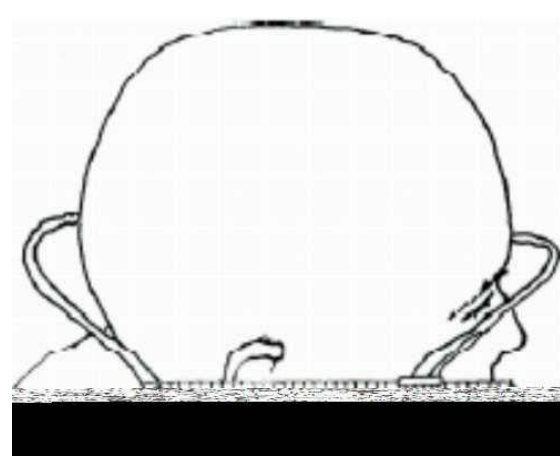

Figure 1: Image showing the head length [7].

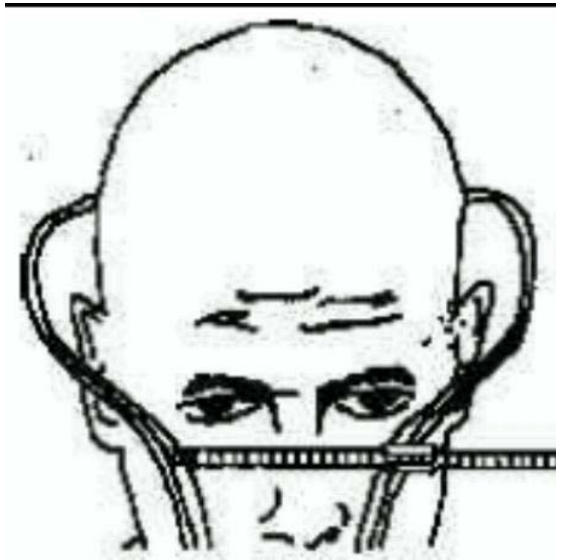

Figure 2: Showing the head width [7]

has his head in an anatomical position. The Data gotten was subjected to statistical analysis.

- Head length was measured to the nearest millimeters (mm) using gliding, sliding caliper or flexible tape with subject seated and head positioned in an upright direction. The head length was measured from the two extreme ends of the sagital axis of the head region using the Anatomical Standard Record of Position such as Frankfurt Plane. Head length is the maximum point on the sagital axis of the skull as shown in Figure 1.

- Head width/breadth was taken from the subject using gliding caliper or flexible tape, measured to the nearest millimeters $(\mathrm{mm})$ when the head is in anatomical position using the Frankurt plane placed from the two extreme ends of parietal axis around the skull. Head width is the maximum point of biparmetal axis around the skull (Figure 2).

\section{Results}

The mean values of the various parameters measured among adult Igbos in Imo state are presented in Table 1 above; the Standard Deviation (SD) from mean is also recorded. Mean Cranial Length 172.34 with a Standard Deviation of 92.89 and mean cranial breadth of 160.46, Standard Deviation of 27.65, the mean age was 33.6 years while mean cephalic index for adult igb os in imo state was 97.26 with a standard deviation os 21.55 .

In Table 2, the classification and distribution of cephalic index
Table 1: Anthropometric parameters of Adult Igbos in Imo state.

\begin{tabular}{|c|c|}
\hline Parameter & Mean \pm SD \\
\hline Cranial length & $172.34 \pm 92.89$ \\
\hline Cranial breadth & $160.46 \pm 27.65$ \\
\hline Age & $33.6 \pm 88.82$ \\
\hline Cephalic index & $97.26 \pm 21.55$ \\
\hline
\end{tabular}

Table 2: Distribution cephalic index among adult Igbos in Imo state.

\begin{tabular}{|c|c|c|c|}
\hline Variable & Options & Frequency $\boldsymbol{n}(\%)$ & p-value \\
\hline \multirow{3}{*}{ Cranial type } & Dolichocephalic & $139(12.0)$ & \multirow{2}{*}{$<0.001$} \\
\cline { 2 - 3 } & Mesaticephalic & $64(5.5)$ & \\
\cline { 2 - 4 } & Brachycephalic & $955(82.5)$ & \\
\hline
\end{tabular}

Table 3: Comparison of Craniofacial Parameters between Male and Female Igbo Adults of Imo State.

\begin{tabular}{|c|c|c|c|}
\hline Parameter & Sex & Mean \pm SD & p-value \\
\hline \multirow{2}{*}{ Cranial length $(\mathrm{mm})$} & Male & $172.92 \pm 18.79$ & \multirow{2}{*}{0.002} \\
\cline { 2 - 4 } & Female & $171.76 \pm 30.06$ & \\
\hline \multirow{2}{*}{ Cranial breadth $(\mathrm{mm})$} & Male & $161.05 \pm 17.21$ & \multirow{2}{*}{$<0.001$} \\
\cline { 2 - 4 } & Female & $159.88 \pm 35.11$ & \\
\hline
\end{tabular}

Table 4: Comparison of Cephalic Indices between Male and Female Igbo Adults of Imo State.

\begin{tabular}{|c|c|c|c|}
\hline Parameter & Sex & Mean \pm SD & p-value \\
\hline \multirow{2}{*}{ Cephalic index (\%) } & Male & $100.23 \pm 26.23$ & \multirow{2}{*}{$<0.001$} \\
\cline { 2 - 4 } & Female & $94.29 \pm 14.94$ & \\
\hline
\end{tabular}

Table 5: Association of Cranial Type and Gender among Igbo Adults of Imo State.

\begin{tabular}{|c|c|c|c|c|}
\hline \multirow{2}{*}{ Cranial Type } & \multicolumn{2}{|c|}{$\operatorname{Sex} n(\%)$} & \multirow{2}{*}{$x^{2}$} & \multirow{2}{*}{ p-value } \\
\hline & Male & Female & & \\
\hline Dolichocephalic & $37(6.4)$ & $102(17.6)$ & \multirow{3}{*}{36.182} & \multirow{3}{*}{$<0.001$} \\
\hline Mesaticephalic & $39(6.7)$ & $25(4.3)$ & & \\
\hline Brachycephalic & $503(86.9)$ & 452 (78.1) & & \\
\hline
\end{tabular}

among adult Igbo's is presented. The most prevalent cranial type among Igbo adults in Imo state is brachycephalic (82.5\%). The other cranial types include dolichocephalic (12\%) and mesaticephalic $(5.5 \%)$.

The mean values of some anthropometric parameters measured among adult males and females in Imo state are shown in Table 3. Mean values were compared in order to assess for differences, hence sexual dimorphism. Result of analysis showed significant difference in mean values of cranial length $($ male $=172.92 \pm 18.79 \mathrm{~mm}$; female $=$ $171.76 \pm 30.06 \mathrm{~mm} ; \mathrm{p}=0.002)$, cranial breadth (male $=161.05 \pm 17.21$ $\mathrm{mm}$; female $=159.88 \pm 35.11 \mathrm{~mm} ; \mathrm{p}<0.001$.

Result of comparison of various craniofacial indices between adult males and females in Imo state is presented in Table 4 above. Significant difference in mean value was found in cephalic index $($ male $=100.23 \pm 26.23 \%$; female $=94.29 \pm 14.94 \% ; \mathrm{p}<0.001)$.

As shown in Table 5 above, a significant difference in prevalence of various cranial types between males and females was seen $\left(\mathrm{X}^{2}=\right.$ 36.182; $\mathrm{p}<0.001)$. Brachycephalic cranial type was significantly more 
prevalent among males (86.9\%) than females (78.1\%). Similarly, mesaticephalic cranial type was observed more among males $(6.7 \%)$ than females (4.3\%). Dolichocephalic cranial type was more common among females (17.6\%) than males (6.4\%).

\section{Discussions}

In all, the mean cephalic index $>80$ was observed in the group studied, the general cephalic index was 97.26. Males had the highest Cephalic Index of 100.23 followed by females 94.29.

Thus, the predominant head type was Brachycephalic (82.5\%). This is in line with the classification of Urhobo and Itsekiri origin of rural and urban areas of Delta state of Nigeria according to [5] their results showed that the cephalic index for both groups was greater than 80 , which puts them at the Brachycephalic populations. The findings of this study demonstrate that there is gender dimorphism in the craniofacial anthropometry and indices of adult Igbo's in Imo state. This finding can be attributed to the fact that males are genetically larger and taller than females; and in addition, puberty occurs in females approximately 2 years earlier than males, therefore the earlier fusion of epiphysis and ossification of bones results in less time for growth of long bones [6]. Furthermore, it is known that there is a relationship between $\mathrm{Y}$ chromosome and height, muscular build. $\mathrm{Y}$ chromosome is associated with increase in linear growth of males [7]. These results agree with the results of other studies that have observed the same pattern in Iranian [3], Indian [8] and Sudanese population [8]. As a result of the gender, dimorphism already established in the present study, the results from the study populations are also gender specific. When findings from this study population were compared with other ethnic groups from Nigeria, from different geographical locations and climatic conditions, some similarities and differences were observed among the ethnic groups. The recorded cephalic index of this study was higher than that of urhobo and Yoruba, very closely related to that of Itsekiri, but lesser than that of Ogoni's. when compared with the male subjects, the Cephalic Index of the females in this study were found to be higher than those of Urhobo females $(87.09 \pm 11.30)$, Itsekiri females $(82.16 \pm 44.74)$, Ogoni females (75.09 \pm 4.75$)$, and Yoruba females (73.75 \pm 5.13$)$ [5]. This may be attributed to the fact that anthropometric measurements vary in different races as a result of biological and environmental factors, which influence gene expressions, growth and maturity of individuals [9-12].

\section{Conclusion}

The mean Cephalic Index of Adults in Imo state has been determined and compared. This should be of relevant importance in national physical anthropometry, forensic investigations and clinical practice.

\section{References}

1. Basu A. Anthropometry of the Kayasthas of Bengal. J Anat Soc India. 1963; 3: $20-25$.

2. El-feghi I, Sid-Ahmad MA, Ahmadi M. Automatic Localization of Craniofacial Landmarks for Assisted Cephalometry. Pattern Recognition. 2004; 57: 609621.

3. Chaurasia. Human Anatomy Volume 3. CBS Publishers \& Distributors Pvt. Ltd. 2000: 2930.

4. GS Oladipo, MO Oyakhire and AA Ugboma Henry. Anthropometric Studies of Nasal Indices of the Ekpeye and IkwerreEthnic Groups in Nigeria. Asian Journal of Medical Sciences. 2010; 2: 167-169.

5. Salter EM, Kolar JC. Thousand Oaks, CA: Sage Reference. Anthropometry. 2007: 35-38.

6. Agarwal C, Garg R, Pareek P, Sharma D, Kumar S. Cranial Anthropometric Indices in Population of Rajasthan, sIndia. Int J Sci Stud. 2017; 5: 73-76.

7. Oladipo GS, Okoh PD, Hart JS. Anthropometric Study of Some Craniofacia Parameters: Head Circumference, Nasal Height, Nasal Width and Nasal Index of Adult ljaws of Nigeria. Asian J Med Sci. 2010; 2: 111-113.

8. Del Prado-Lu JL. Anthropometric Measurement of Filipino Manufacturing Workers. International Journal of Industrial Ergonomics. 2007; 37: 497-503.

9. Bhargava I, Kher GA. A Anthropometric Study of Central India Bhils of Dhar District of Madhya Pradesh. J Anat Soc India. 2009; 9: 14-19.

10. Alabi SA, Didia BC, Oladipo GS, Aigbogun EO. Evaluation of Sexual Dimorphism by Discriminant function analysis of Toe length (IT=ST) of Adult Igbo Populace in Nigeria. Nigerian Medical Journal. 2016; 57: 226-232.

11. Anibor E, Okumagba MT, Avwioro OG. Photometric facial analysis of the Itsekiri ethnic group of Nigeria. Arch Appl Sci Res. 2010; 2: 219-222.

12. Obaje SG, Hamman WO, Ibegbu AO and Waitieh-Kabehl AK. Anthropometric study of cephalometric indices among Idoma and Igede ethnic groups of Benue State, Nigeria. Int J Med Biomed Res. 2015; 4: 21-34. 